\title{
THE EFFECT OF THE CHANGES IN ACCOUNTING ESTIMATES OF THE DISCOUNT RATE TO THE COSTS ON ACCOUNT OF CREATING PROVISIONS*
}

\author{
Anna Staszel \\ Cracow University of Economics, Cracow, Poland \\ e-mail: staszela@uek.krakow.pl \\ ORCID: 0000-0002-4577-6262
}

\author{
Artur Hołda \\ Cracow University of Economics, Cracow, Poland \\ e-mail: aholda@uek.krakow.pl
}

ORCID: 0000-0001-7744-2905

(C) 2019 Anna Staszel, Artur Hołda

This is an open access article distributed under the Creative Commons Attribution-NonCommercial-NoDerivs license (http://creativecommons.org/licenses/by-nc-nd/3.0/)

DOI: 10.15611/fins.2019.1.06

JEL Classification: M41

\begin{abstract}
Summary: The aim of the study is to answer the question of how a slight change in the actuarial assumptions (regarding the discount rate used) can affect the amount of the provisions, and consequently create the level of costs in the entity. In order to find the answer the financial statements of 148 stockexchange-quoted companies from 2007 to 2014 (1184 financial statements in total) were analysed, determining whether the changes in long-term provisions for retirement benefits provisions (due to the use of a different discount) have a significant impact on the financial statements of these companies. The research involved the use of deductive-inductive research methods in the form of literature review and analysis of the content of financial statements. The obtained results indicate that the estimation of the discount rate significantly affects the levels of costs related to creating provisions, which may be an effective tool for manipulating the financial result.
\end{abstract}

Keywords: discount rate, long-term provisions, reliability of financial statements, estimations, true and fair view.

* This publication was funded out of the financial resources of the Polish Ministry of Science and Higher Education granted to the Cracow University of Economics' Department of Management towards the research of young scientists and Ph.D. students. 


\section{Introduction}

Provisions constitute a category which, as proved by numerous scientific studies conducted in Poland and around the world [Walińska, Bęk-Gaik 2012; 2010; Peek 2004; Micherda 2009], may significantly shape the financial results of companies. Particularly prone to manipulations is the provision for long-term retirement benefits estimated based on numerous subjective assumptions [Amen 2008; Glaum et al. 2018; Hsu et al. 2013; Ljubicic 2010].

The obligation to create provisions results from the accounting assumptions themselves, i.e. from the necessity of presenting all the liabilities in the balance sheet (also those uncertain ones) and the financial result of the financial year actually achieved by the entity. Accounting provisions make it possible to recognize the existing risk and to protect itself against its negative impact [Gierusz 2005, p. 99]. Nevertheless, what seems to be most important, creating, reversing and using the provisions is necessary if an entity wants to present a true and fair financial result for a given reporting period and therefore a true picture of the economic entity in the financial statement [Duraj 2003, p. 37]. Unfortunately, the provisions - being a special area, both in theory and practice - can be used as a tool for creating a financial result, which constitutes a problem that can affect almost every market participant who makes decisions on the basis of distorted reporting information.

Provisions are an example of how complex and difficult a valuation in accounting can be [Gos, Hońko 2013, p. 74]; estimating the amount of provisions requires the adoption of numerous assumptions related to the future events and estimating the probability of their occurrence. When estimating provisions, there is no certainty as to whether the negative phenomenon against which the provision should protect will take place at all, therefore the signs of its occurrence can only be assessed, and what seems most important, the provisions incorrectly created, released and used distort the picture of an economic entity in the financial statement in two reporting periods, at the time of creating the provision and its release or use [Gierusz 2005, p. 100].

Particularly problematic provisions are the provisions related to employee benefits which the entities expect to incur in the future. The current value of these benefits is usually defined as the sum of the products of the predicted present nominal value of the benefit, the demographic probability of payment of the benefit as well as the discounting rate. The adoption of the actuarial assumptions determines de facto the amount of the provision for employee benefits, and the amount of the created provision is accounted for as an operating expense (the costs of distribution or administrative activities depending on the positions of the employees). The authors put forward the hypothesis that even a slight change in the assumptions regarding the discount may significantly affect the amount of the long-term provision for retirement benefits presented in the financial statement of the entity. The aim of the study is to answer the question of how a slight change in the actuarial assumptions (regarding the discount rate used) can affect the amount of the provisions, and 
consequently create the level of costs in the entity. The research involved the use of deductive-inductive research methods in the form of literature review and analysis of the content of financial statements.

\section{Provisions for employee benefits - the methodology of estimating the amount of provisions}

In accordance with IASC 6 and IAS 19, an entity is obliged to recognize liability if the employee performed a service in exchange for employee benefits which are to be paid in the future, and the costs if the entity uses economic benefits resulting from the service performed by the employee in exchange for the employee benefits.

The notion of employee benefits covers not only all forms of the entity's benefits offered in exchange for the service performed by employees, but also the benefits, for instance, for persons who are their dependants (made in the form of direct payment to employees, or their spouses, or children). Moreover, in accordance with IAS 19, the entity's employee is not only a full-time employee, but also every employee employed by the entity regardless of the form of employment and working time. An employee is also considered a member of management (e.g. the members of the entity's management board).

For an economic entity, the employee benefits are liabilities resulting from both the formalized plans used in the entity, the arrangements between the entity and its employees, legal or industrial requirements as well as from various other informal practices [Poniatowska 2012].

Employee benefits for reporting purposes are divided into: [Kuzior 2014, p. 99]:

a) short-term employee benefits, which include (if they are due within 12 months of the balance-sheet date) remuneration for service, social insurance contributions, paid holiday leave, sick leave and profit-sharing or bonuses. Short-term benefits also involve benefits in kind (e.g. company car or medical care);

b) post-employment benefits: pensions and other retirement benefits, life insurance or medical benefits after termination of employment;

c) other long-term employee benefits, including long-term pension benefits and the benefits that are not paid in total within twelve months of the end of the period, e.g. shares in profits, bonuses, or deferred compensation, e.g. leave granted to employees for seniority of service (sabbatical leave, 'jubilee' benefits, etc.);

d) termination benefits include payments which occur as a result of the termination of the employment relationship with an employee before he/she reaches retirement age.

Measurement of the short-term employee benefits does not raise any doubts. These benefits are recognized in the amount being the expected, undiscounted amount of the benefit. 
If the entity is obliged to make, for example, obligatory payments for the absence of the employee from work, then:

a) if these benefits are non-cumulative (e.g. sick pay), they are recognized as a current cost;

b) if the benefits are cumulative (e.g. paid holidays), the entity's obligation increases with the employees' performance, and increases their rights to the subsequent paid absences. An entity should recognize the payments of the accumulated absences when the employees performed his service, as accrued expenses [Hołda 2015, p. 119].

Post-employment benefits include the benefits which are related to the employee's withdrawal from professional life, e.g. retirement, life insurance or post-employment medical care.

The entity's activity may also be included in a benefit plan in which the entity itself undertakes to pay defined benefits after the employment term to the currently employed and former employees, with the actuarial risk (that the benefits will cost more than expected) and investment risk charged to the entity. An example of such benefits are retirement benefits on which the entity's future liabilities due to employees are based, which means the necessity of creating a provision. In the case of, for example, the limitation of the benefits resulting from the plan, the previously created provision is reduced. In addition, income and expenses due in the settlement of the retirement benefits plan, include [Hołda 2013]:

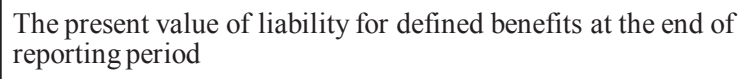

Fig. 1. Determination of provision for defined benefits

Source: own elaboration based on [Hołda 2015, p. 121]. 
- changes in the present value of liabilities due to defined benefits,

- changes in the fair value of the plan assets,

- actuarial gains and losses, and the past-service costs that have not been recognized yet.

The algorithm of calculating the balance sheet value of the liabilities for defined benefits pursuant to IAS 19 is contained in Figure 1.

The current (present) value of the liability is, in a very simplified way, the discounted value of the future payments to employees which should be calculated considering inter alia demographic data (e.g. 'mortality') and financial data (e.g. inflation) [Poniatowska 2011, p. 261].

Actuarial gains and losses means a change in the present value of liability resulting from adjustments to the adopted actuarial assumptions. The past-service costs occur in the course of changing the rules in a defined benefit plan, and they may have a positive value (when benefits are introduced or conditions are changed to more favourable) or negative (when limiting the existing benefits). An entity presenting its liability for defined benefits should recognize past-service costs with the linear method for the average period of the acquirement of rights to those benefits. If the rights to the benefits are acquired immediately after the plan is introduced or changes are made to the plan, the past service cost is immediately recognized. The fair value of the plan assets includes the assets of fair value which are only to pay or fund the employee benefits. If the market price is unavailable, the fair value of the plan assets may be determined by discounting expected future cash flows using a discount rate which reflects the risk related to the plan assets and expected payment term or expected term for disposal of the assets. The expected return on the plan assets is one of the elements of costs recognized in the profit and loss account, and the difference between the expected return and actual return on plan assets constitutes actuarial profit or loss.

Interest costs constitute an increase within a given period of the present value of defined benefit liability which arise as a result of the fact that the benefits are one period closer to settlement.

If the liability balance sheet value determined in the above mentioned manner turns out to be negative, the entity should measure the asset component in the amount whichever of these two amounts is lower:

- the present value of economic benefits available in the form of a refund from the plan or a reduction in future contributions to the plan,

- all unrecognized actuarial losses and past-service costs.

- In turn, in the profit or loss of a given period, an entity should recognize the revenues or costs as a sum of the following amounts:

a) current service costs,

b) interest costs,

c) the expected return on plan assets and possible entitlement to compensation, 
d) actuarial gains or losses, as required in accordance with the entity's accounting policy,

e) past-service costs,

f) the effect of any curtailments or settlements,

g) the effect of specific curtailments.

The example of estimating the provision for retirement benefits presents the elements related to the estimation of the provisions for retirement benefits that shape the entity's financial result, affecting inter alia the amount of the costs presented in the reporting period.

\subsection{An example of estimating provision for retirement benefits. The effects of a change to the assumptions considering the discount rate used}

Assuming that each employee in the economic entity after reaching retirement age is entitled to a one-time benefit which is three times higher than his/her last remuneration (i.e. the remuneration received on the date of retirement), it is necessary to recognize the benefit for the newly employed in the entity. An employee has just been employed and in 6 years will reach retirement age, and his/her salary amounts to PLN 8 000. Furthermore, an average annual wage growth by $2 \%$ and the discount rate by $8 \%$ are estimated. Based on demographic assumptions, there is an $80 \%$ chance for this type of employee to achieve a 6-year job seniority.

Based on the above-mentioned assumptions, it is possible to estimate employee benefits with the method of individual rights:

- the probability of working one year by an employee: $p=\sqrt[6]{0.8}=96.35$,

- the future value of the benefit acquired amounts to: $8000 *(1.02)^{6 * 2}=18019$,

- the value of the benefit for one year amounts to: $18019 / 6=3003$.

Considering the discount rate $r=8 \%$ and 6 -year benefit period $(k=6)$, it is possible to determine the value of the present employment, the costs of current employment and interest, as shown in Table 1.

Table 1. The value of the present employment, the costs of current employment and interest

\begin{tabular}{|l|c|c|c|}
\hline Periods & $\begin{array}{c}\text { The amount } \\
\text { of current liabilities }\end{array}$ & Current service costs & Interest \\
\hline 1 & PLN 1 697 & PLN 1 635 & \\
\hline 2 & PLN 3 805 & PLN 1 833 & PLN 136 \\
\hline 3 & PLN 6 397 & PLN 2 054 & PLN 304 \\
\hline 4 & PLN 9 560 & PLN 2 303 & PLN 512 \\
\hline 5 & PLN 13 396 & PLN 2 581 & PLN 765 \\
\hline 6 & PLN 18 019 & PLN 2 893 & PLN 1 072 \\
\hline
\end{tabular}

Source: own elaboration based on an analysis of the data contained in financial statements of the listed companies, made available by those companies on their websites. 
For instance, the accounts of the fifth period:

- the amount of the current liabilities amount to:

$$
W B Z_{5}=\frac{3003 * 5}{(1.08)^{6-5}} * 0.9635^{6-5}=13396 ;
$$

- the current service costs amount to:

$$
K B Z_{5}=\frac{3003}{(1.08)^{6-5}} * 0.9635^{6-5+1}=2581 .
$$

Interest amounts to: $9560 * 8 \%=765$.

The increase in the value of the provision is therefore 3836 (i.e. 13396 -9560), when the current service costs amount to 2581 , and the interest to 765 . The remaining amount (PLN 490) is an increase in the probability of the benefit payment.

Actuarial profits and losses should be recognized directly in the entity's income or expenses (since 2013 the so-called corridor method is no longer applicable). In addition, the standard indicates an appropriate method for presenting changes in liabilities and assets of a defined benefit plan under three categories:

- service costs (include the current and past service costs, and the gains and losses on settlement) are recognized in the financial result,

- net interest (calculated using the discount rate at the beginning of the reporting period to the net amount of a liability or asset resulting from a defined benefit plan at the beginning of each reporting period) is recognized in the financial result,

- revaluation that includes actuarial gains and losses from defined benefit liabilties, a surplus of actual gain on the plan assets over the changes in the value of these assets over time, as well as any changes resulting from the applied asset value limit is recognized in other comprehensive income.

For example, if an entity changes the discount rate from $8 \%$ to $7 \%$ in the fifth year:

- the value of the current liability at the new discount rate will amount to:

$$
W B Z_{5}=\frac{3003 * 5}{(1.07)^{6-1}} * 0.9635^{6-1}=13521 ;
$$

- the current service costs at the new discount rate will amount to:

$$
K B Z_{5}=\frac{3003}{(1.07)^{6-1}} * 0.9635^{6-5+1}=2605 ;
$$

- there is a decrease in estimated current liabilities and an actuarial gain of 125 (i.e. $13396-13$ 521);

- at the same time, the change in the provisions refers to the difference between the balance of liabilities estimated at the end of the fourth year when using the previous discount rate and the liability estimated at the end of 5 years with new 
assumptions) and also includes an actuarial loss equal to 3961 (i.e. $13521-$ 9560).

The above solutions correspond with the IAS. According to the Accounting Act regulations, the employee benefits can be long-term and short-term, without providing such extensive systematics and thus not requiring such disclosures. The Accounting Act also does not include the requirement of valuation of the benefits using the full actuarial method, and the accounting recognition of the employee benefits is made through accrued liabilities, despite the fact that their presentation in the financial statements takes place as the item of provisions.

In summary, presenting the provisions for employee benefits in the financial statement requires [Warelis 2011, p. 308]:

- measurement of the provisions for employee benefits and its presentation in the balance sheet (with proper recognition of the costs),

- if the provisions are created for the first time, they are recognized as an error from previous years and presented in the balance sheet as a loss from the previous years,

- due to the creation of a provision, deferred income tax assets are recognized.

One may withdraw from the obligation of creating provisions only when the estimated provision value is irrelevant to the financial statement.

There is no doubt that the accounting regulations currently applicable to the provisions leave a large margin of freedom, which may be used to manipulate the financial result, especially because the effects of the evaluation of provisions for employee benefits can affect the amount of the costs recognized in the reporting period. In particular the change in the applied discount rate may result in a significant change in the estimates made to the amount of long-term provision for employee benefits.

\section{Determining discount rates}

It is obvious that the present categories are more valuable than the same categories, but of the future. This is caused by, for example:

- Technology progress (relating to, e.g. improvement of the factors and processes applied in business operations, changing the relations of effects to inputs). As a result of technological progress, in the future the same effects are easier to obtain and require less expenditure, so they are less valued and less valuable for the humankind.

- Economic risk (the probability of not reaching the desired effects and the uncertainty of future economic conditions). The future effects are risky and uncertain, less certain and therefore less valuable.

- Interest rate on the capital market (the interest rate may be defined as the price paid by the market for withdrawing from the current consumption in favour of the future consumption). 
- Inflation (decrease in the purchasing power of money).

The above-mentioned factors make the categories that appear today not identical with the categories appearing in the future, hence the problem of comparing monetary categories with several time periods. One of the methods of reducing the monetary categories from different time periods to comparability is to use a discount. The discount expresses - in percentage terms - the rate of currency depreciation. Thus, the estimation of a discount should also include an analysis of the four factors listed above. In addition, the discount should also take into account the risk, generally, related to the future,

Using another approach, the discount rate should represent the income that can be obtained by investing money in the best alternative investment with a similar level of risk [Brigham, Gapenski 2000, p. 30]. It can be also said that the expected rate (required) by investors, both owners and creditors, determines the cost of capital used by the company [Duliniec 2001, p. 67]. The appropriate discount rate can be, for instance, the cost of equity measured in accordance with the Capital Asset Pricing Model (CAPM) or the Weighted Average Cost of Capital (WACC).

Considering the problems associated with determining the appropriate discount rate in the aspect of creating provisions, it should be remembered that during the social consultations conducted before implementing the new rules of IAS 19, most of the questions and comments of the respondents were exactly about these problems and the doubts related to the choice of the appropriate discount rate [Demaria et al. 2012].

\subsection{Characteristics of the CAPM model}

CAPM (Capital Basset Pricing Model), as a part of the capital market theory, is one of the most popular method of estimating a company's cost of equity capital. ${ }^{1}$ The basic assumption of the model [Sharpe 1964] is determining that a part of the risk premium on the expected return on investment in securities is a function of security market risk, as a result of which the CAPM model refers also to the theory of portfolio [Grabowski, Pratt 2008, p. 80]. In practice, when measuring the cost of equity using the CAPM model, the assumed return rate required by investor depends on the return on risk-free investments as well as the risk premium, specific for defined investment, according to the following equation:

$$
C_{e}=r_{R F}+\beta *\left(r_{M}-r_{R F}\right),
$$

where: $C_{e}$ - the cost of equity from retained earnings; $r_{R F}$ - the rate of return of a risk free security; the rate is usually calculated on the basis of the yields for government securities (which are considered as the safest financial instrument), e.g. using rates of treasury bonds or treasury bills; $r_{M}$ - the rate of return on representative

\footnotetext{
${ }^{1}$ The CAPM model was independently formulated by W. Sharpe, J. Lintner, J. Mossin and J. Treynor.
} 
investments to the market portfolio which, in practice, is difficult to estimate, and so it is often assumed that it is the rate of return on the major stock market index; $\beta$ - index for defining the level of systematic risk (i.e. the measure of correlation between the asset's returns and the market returns). Coefficient $\beta$ defines the level of market risk related to investing in assets by a specific company and it depends inter alia on the type of activity the economic entity runs, structure of its assets, or financial sources. In practice, this reflects the volatility of a company's stock prices in comparison to the volatility of the whole index. $\beta$ is calculated by the simple regression method, measuring the noticeable historical relationship between the change in the company's share prices increased by dividend profits and the change in prices on the securities market [Ogier et al. 2004, p. 43]. Coefficient $\beta$ greater than 1 means that the investment is an investment of higher risk, while less than 1 indicates that the company is characterized by a relatively low risk [Rakow 2010, p. 43].

\subsection{Assumptions of the WACC model}

The WACC (Weighted Average Cost of Capital) determination procedure is based on estimating the cost of capital from individual sources of a company's financing and calculating the share of each of these capitals in the structure of the entity.

The weight reflecting the share of particular types of capital in the total value of assets invested in the company should be determined on the basis of market values. The basic categories of capital include debt capital, ordinary share capital and preferred share capital, hence the basic formula for WACC is as follows:

$$
W A C C=w_{d} * k_{d} *(1-T)+w_{e} * k_{e},
$$

where: $K_{d}-$ cost of debt; $K_{d}-$ cost of equity; $W_{d}$ - share of equity; $W_{e}-$ share of debt; $T$ - the income tax rate paid by the company.

The major source of equity is the capital provided by owners (i.e. share capital and retained earnings). It is assumed that the capital from retained earnings is equal to the rate of return obtained by the stock holders of ordinary shares (because if they did not achieve the required rate, they would decide to pay a dividend and invest it independently). The most popular theoretical models for determining the cost of capital from the issuance of ordinary shares are:

a) the Gordon model for retained earnings, the calculations then arise from the formula:

$$
k_{e}=\frac{D_{0} *(1+g)}{P_{e}}+g
$$


b) Gordon's model for the new issue

$$
k_{e}=\frac{D_{0} *(1+g)}{P_{e}-F}+g
$$

c) the CAPM model

$$
k_{e}=k_{R F}+\beta *\left(k_{M}-k_{R F}\right)
$$

d) a model based on the rate of return on bonds

$$
k_{e}=k_{R F}+\beta *\left(k_{M}-k_{R F}\right)
$$

where: $k_{e}$ - the cost of capital on the issue of ordinary shares; $k_{d}$ - the required rate of return on corporate bonds; $k_{r f}$ - risk-free rate of return; $k_{m}$ - rate of return on market portfolio; $D_{0}$ - dividend paid in the last year; $P_{e}$ - the current market price of ordinary share; $F$ - the amount of issue costs per share; $g$ - growth rate of dividend; $\beta$ - company's beta; $R P$ - risk premium.

Unfortunately, in calculating the WACC one can face the problem of the so-called 'vicious circle', because for calculating weights based on market values, it is necessary to know the value of the company's past activity beforehand, and to determine this value the WACC is required. This problem can be easily solved considering the stock exchange quoted companies, whereas for those entities that are not subject to market valuation, the weighting is most often carried out on the basis of book values.

\section{Analysis of discount rate sensitivity to changes in the assumptions of the amount of factors accepted for its estimation}

In order to check how much the amount of provision (PLN 10,000) can vary if a different discount rate was applied, a sensitivity analysis was carried out by:

1) checking whether the value of the discount rate, calculated as the cost of equity in accordance with the CAPM model, given that the adopted values of Rf and $\mathrm{Rm}$ will change by $0.5 \%$ at a content level $\mathrm{B}=0.8$;

2) checking how much the value of the discount rate, calculated as the cost of equity in accordance with the CAPM model, will change, assuming that the adopted values of $\mathrm{Rf}$ and $\mathrm{Rm}$ will change by $0.5 \%$, at a constant level $\mathrm{B}=1.2$;

3) checking how much the value of the discount rate, calculated as the cost of equity in accordance with the CAPM model, will change, assuming that the adopted values of $\mathrm{Rf}$ and $\mathrm{Rm}$ will change by $0.5 \%$, at a constant level $\mathrm{B}=1.2$;

4) checking how much the value of the discount rate, calculated as the cost of equity in accordance with the WACC model, will change, assuming that the adopted interest rate of equity and debt capital changes by $0.5 \%$. 
The adopted base values are: $R f=9.5 \%, R m=3.5 \%, K e=8.5 \%, K d=11.5 \%$. It is not so important whether the assumed base values are smaller or larger for further analysis, because the purpose of the research is measuring how a change in one parameter will affect the discount rate. In the sensitivity analysis, it was assumed that $\mathrm{B}=1.2$ or 0.8 . The $\mathrm{B}$ factor should take into account market data, while an economic entity, estimating the discount rate based on the CAPM model refers to the value of the Beta factor, considering a number of additional factors, such as the characteristics of the industry in which it operates.

Table 2. Discount rate (sensitivity analysis) calculated model as the cost of capital in accordance with the CAPM. A change in $r m$ by $0.5 \%$ and $r f$ by $0.5 \%$, assuming that $\mathrm{B}=0.8$

\begin{tabular}{|l|c|c|c|}
\hline \multicolumn{1}{|c|}{ Data in PLN thousand } & $r m=3 \%$ & $r m=3.5 \%$ & $r m=4 \%$ \\
\hline$r f=9 \%$ & $3.048 \%$ & $3.544 \%$ & $4.040 \%$ \\
\hline$r f=9.5 \%$ & $3.052 \%$ & $3.548 \%$ & $4.044 \%$ \\
\hline$r f=10 \%$ & $3.056 \%$ & $3.552 \%$ & $4.048 \%$ \\
\hline
\end{tabular}

Source: own elaboration based on the analysis.

Table 3. Discount rate (sensitivity analysis) calculated as the cost of capital in accordance with the CAPM model. A change in $r m$ by $0.5 \%$ and $r f$ by $0.5 \%$, assuming that $\mathrm{B}=1.2$

\begin{tabular}{|l|c|c|c|}
\hline \multicolumn{1}{|c|}{ Data in PLN thousand } & $r m=3 \%$ & $r m=3.5 \%$ & $r m=4 \%$ \\
\hline$r f=9 \%$ & $3.072 \%$ & $3.566 \%$ & $4.060 \%$ \\
\hline$r f=9.5 \%$ & $3.078 \%$ & $3.572 \%$ & $4.066 \%$ \\
\hline$r f=10 \%$ & $3.084 \%$ & $3.578 \%$ & $4.072 \%$ \\
\hline
\end{tabular}

Source: own elaboration based on the analysis.

The sensitivity analysis showed that only a one percent change in the parameters used to determine the discount rate means that the discount rate also changes by $1 \%$.

Finally, the change in parameters changes the discount by $1 \%$.

Table 4. Discount rate (sensitivity analysis) calculated as the cost of capital in accordance with the WACC model. A change in $k d$ by $0.5 \%$ and $k e$ by $0.5 \%$, assuming that equity accounts for $50 \%$ and debt capital accounts for $50 \%$ of the total assets

\begin{tabular}{|l|c|c|c|}
\hline \multicolumn{1}{|c|}{ Data in PLN thousand } & $k e=8 \%$ & $k e=8.5 \%$ & $k e=9 \%$ \\
\hline$k d=11 \%$ & $8.455 \%$ & $8.705 \%$ & $8.955 \%$ \\
\hline$k d=115 \%$ & $8.658 \%$ & $8.908 \%$ & $9.158 \%$ \\
\hline$k d=12 \%$ & $8.860 \%$ & $9.110 \%$ & $9.360 \%$ \\
\hline
\end{tabular}

Source: own elaboration based on the analysis.

If WACC is assumed as the discount rate, a one-percent change in the model parameters will cause the discount rate to change by $0.905 \%$.

Analyzing the sensitivity of the discount rate estimated with the WACC model, it was assumed that the ratio of equity to foreign capital is 50:50. The sensitivity 
analysis was used only to simulate how the discount rate changes in the case of the parameters changing. However, it was also checked how the discount rate will change if it is recognized that the equity accounts for $58 \%$ of the entity's liabilities. In a later part of the article, a research sample will be presented, in which 115 companies acknowledge the state of pension reserves at least 4 times over the years examined. The average level of equity share in total assets in the group of those 115 companies analyzed is exactly $58 \%$.

Table 5. Discount rate (sensitivity analysis) calculated as the cost of capital in accordance with the WACC model. A change in $k d$ by $0.5 \%$ and $k e$ by $0.5 \%$, assuming that equity accounts for $58 \%$ and debt capital accounts for $42 \%$ of the total assets

\begin{tabular}{|l|c|c|c|}
\hline \multicolumn{1}{|c|}{ Data in PLN thousand } & $k e=8 \%$ & $k e=8.5 \%$ & $k e=9 \%$ \\
\hline$k d=11 \%$ & $8.382 \%$ & $8.672 \%$ & $8.962 \%$ \\
\hline$k d=11.5 \%$ & $8.552 \%$ & $8.842 \%$ & $9.132 \%$ \\
\hline$k d=12 \%$ & $8.722 \%$ & $9.012 \%$ & $9.302 \%$ \\
\hline
\end{tabular}

Source: own elaboration based on the analysis.

If WACC is assumed as the discount rate, a one-percent change in the model parameters will cause the discount rate to change by $0.92 \%$ (the difference in the results is slightly higher than when the equal share of foreign and equity capital in the balance sheet total is assumed).

Analysing the provision of PLN 10,000 and assuming that the discount rate of $9 \%$ may be reduced or increased by $1 \%$, it was checked how this change may affect the final amount of the provision, assuming that it is discounted for a period of one to five years.

The results are summarized in Table 6 .

Table 6. Results of analysis

\begin{tabular}{|l|c|c|c|c|c|}
\hline $\begin{array}{c}\text { Provision in } \\
\text { the amount of } \\
\begin{array}{c}\text { PLN 10,000, } \\
\text { discount for a } \\
\text { period }\end{array}\end{array}$ & $\begin{array}{c}\text { Adopted } \\
\text { discount } \\
8 \%\end{array}$ & $\begin{array}{c}\text { Adopted } \\
\text { discount } \\
9 \%\end{array}$ & $\begin{array}{c}\text { Adopted } \\
\text { discount } \\
10 \%\end{array}$ & $\begin{array}{c}\text { The difference } \\
\text { between the discount } \\
\text { application of } 8 \% \text { and } \\
\text { the discount of 9\% } \\
\text { (calculated as a \% of } \\
\text { the provision in the } \\
\text { value with a discount } \\
\text { of 9\%) }\end{array}$ & $\begin{array}{c}\text { The difference } \\
\text { between the discount } \\
\text { application of } 8 \% \\
\text { and the } 10 \% \text { discount } \\
\text { (calculated as a \% of } \\
\text { the reserve in value } \\
\text { with the discounted } \\
8 \%)\end{array}$ \\
\hline 1 year & 9259.26 & 9174.31 & 9090.91 & $0.93 \%$ & $1.85 \%$ \\
\hline 2 years & 8573.39 & 8416.80 & 8264.46 & $1.86 \%$ & $3.74 \%$ \\
\hline 3 years & 7938.32 & 7721.83 & 7513.15 & $2.80 \%$ & $5.66 \%$ \\
\hline 4 years & 7350.30 & 7084.25 & 6830.13 & $3.76 \%$ & $7.62 \%$ \\
\hline 5 years & 6805.83 & 6499.31 & 6209.21 & $4.72 \%$ & $9.61 \%$ \\
\hline
\end{tabular}

Source: own elaboration based on the analysis. 
If the amount of PLN 10,000 is discounted over a 5-year period, a change of the discount rate by $1 \%$ results in a change in the provision amount by as much as $4.72 \%$, while a change in the discount rate by $2 \%$ results in a nearly $10 \%$ difference in the provision.

In the case of discounting for only 3 years, a one-percent discount change will result in a $2.8 \%$ change in the provision, but in the case of a two-percent change in the discount, the provision amount will change by $5.66 \%$.

\section{Impact of the changes in the discount rate on the amount of provisions recognized in the financial statements of listed companies}

\subsection{Characteristics of the research sample}

A study was conducted with a group of randomly selected 148 Polish companies listed on the Stock Exchange which are not financial institutions and which prepare their financial statement in accordance with Annex 1 to the Accounting Act or IAS. The study covered the data included in the financial statements of 148 companies from 2007 to2014, which means that 1184 financial statements were analysed in total. In the first stage of the study the financial statements were analysed in terms of the information related to the creation of short and long-term provisions for employee benefits. The results of this study showed that in the financial statements of the entities involved, in all the 8 years covered with the study, the long-term provisions prevailed among all the provisions for employee benefits, constituting over four-fifths. The time structure of the recognized provisions and accrued expenses for employee benefits are shown in Figure 2.

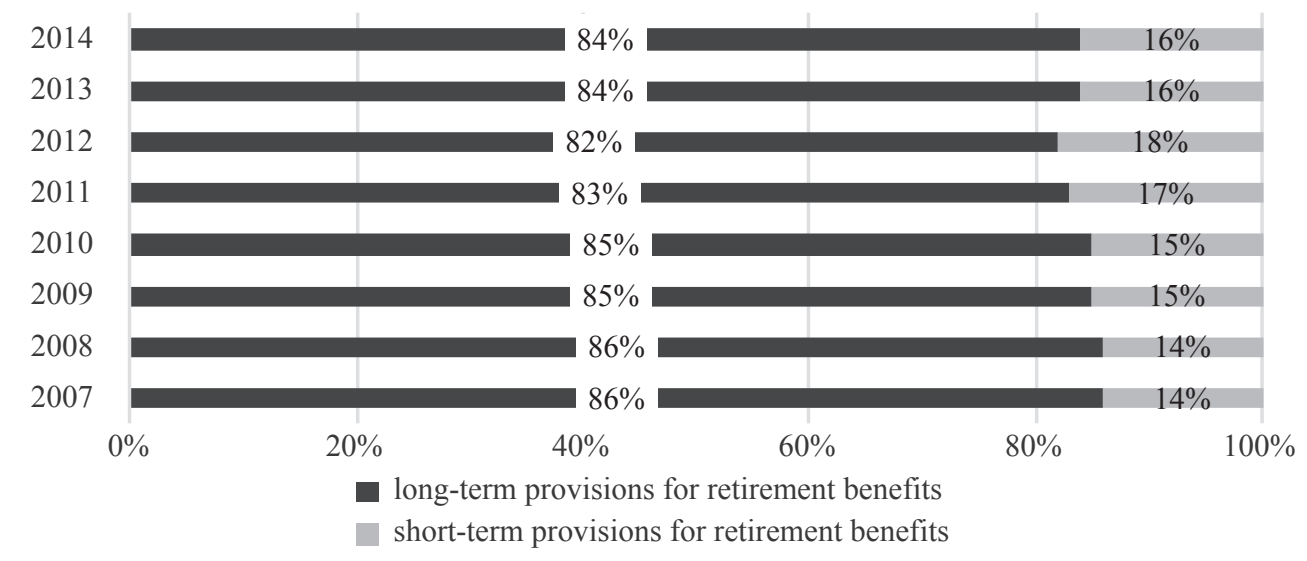

Fig. 2. Time structure of the provisions and accrued expenses created for employee benefits

Source: own elaboration based on an analysis of the data contained in the financial statements of the listed companies, made available by those companies on their websites. 
Subsequently, a detailed analysis was made (on the basis of additional notes to financial statements) as to for which items exactly entities create positions to recognize them as provisions for retirement benefits.

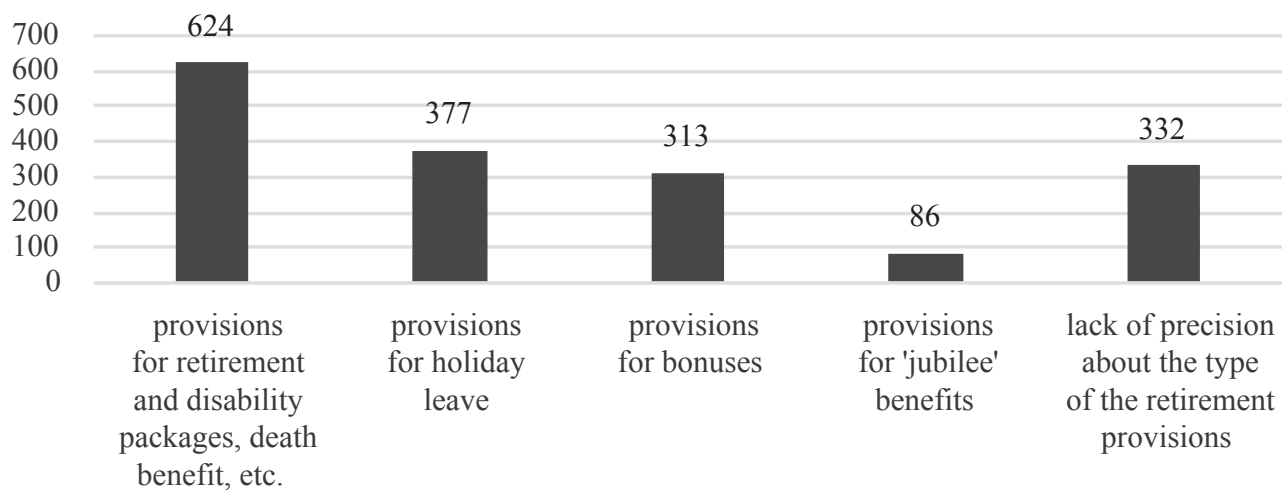

Fig. 3. Recognized types of provisions for employee benefits in the financial statements

Source: own development based on an analysis of the data contained in financial statements of the listed companies, made available by those companies on their websites.

From among those 1184 financial statements, as many as in 624 statements, the entities presented provisions for retirement and disability packages, death benefit, etc. In almost $30 \%$ of the statements the entities presented provisions for holiday leave, provisions for bonuses or presented general amounts of the provisions for employee benefits, not specifying their type. In 86 statements, the entities indicated that they create provisions for 'jubilee' benefits.

For further analysis, from among those 148 companies we selected those which each year (from the eight years covered by the study) presented provisions for longterm employee benefits. There were 68 companies that had long-term provisions for employee benefits in each of the years covered by the study, which is almost a half, $45 \%$ of the entities in total.

Next, based on the data included in the financial statements of those 68 companies from 2007 to2014, an average partial materiality rate for items, long term provisions for employee benefits and partial materiality (relevance) for the gross financial result were calculated for those entities, for all years.

\subsection{Methodology of determining materiality limits for particular elements of the financial statement and the statement as a whole}

Information is considered material if its omission or misstatement could substantially affect the decision of the user of the financial statements. In practice there are numerous models allowing to establish the materiality limit for financial statements. The authors of this study, adopting the viewpoint of the recipient of economic 
information, propose a materiality calculation model referring to the basic economic categories disclosed in the financial statements. The authors suggest that overall materiality should be calculated as the arithmetic mean of the four quantities (all factors have the same weight assigned), which are [Hołda 2013, p. 333]:

- $1 \%$ balance sheet total,

- $1.4 \%$ equity capital,

- $0.8 \%$ sum of revenues from the sale of products and goods,

- $8 \%$ gross financial result.

The overall materiality calculated this way applies to the financial statements as a whole. If this limit is exceeded, it means that the financial report may contain significant distortions that may influence the decisions of the users of financial statements.

The concept of materiality (significance) applies not only to the entire report, but also to its individual items (such as provisions for retirement benefits) or groups of items (e.g. total provisions). Therefore, in addition to calculating the overall materiality, indicating an acceptable maximum error (simplification) in relation to the entire financial statement, it is advisable to determine the level of partial (specific) materiality for individual items or groups of items in the financial statements. The partial materiality is calculated according to the formula:

$$
M_{p}=M_{o} * \sqrt{\frac{\text { amount of item or group of items of the financial statement }}{\text { the component of financial statement wherethe given item is }}}
$$

where: $M_{p}$ - partial materiality; $M_{o}$ - overall materiality component of financial statement - balance sheet, profit and loss account, cash flow statement.

The proposed methodology for calculating materiality based on objective criteria can be applied to each reporting item as well as to any economic entity, regardless of the size of the entity, the industry in which it operates or the specific nature of its business [Hołda, Staszel 2018].

The analysis was conducted for 68 companies and also in a cross-section, by calculating materiality rates for the entities listed on WIG30, mWIG40, sWIG80 and the stock exchange companies not listed on any of the indices mentioned. The results of the materiality calculations, together with the average balance of long-term provisions for employee benefits, are shown in Table 7.

As part of the research, calculations were also made as to whether the changes of $3 \%, 6 \%$, and $9 \%$ of the average balance of provisions (which, as proved earlier, may only result from a change in the discount rate estimate by $1 \%$ ) exceed the determined partial materiality. In the case of changes in the provision by $9 \%$ in each of the groups, such a change is material. In the case of a change in the provision by $6 \%$, this change is material for the largest entities (listed on the WIG30) and in aggregate for all entities. 
Table 7. Companies presenting provisions in the entire period covered by the study ( 8 years)

\begin{tabular}{|l|c|c|c|c|c|c|}
\hline Entities & $\begin{array}{c}\text { The } \\
\text { average } \\
\text { balance } \\
\text { of long-term } \\
\text { provisions } \\
\text { for employee } \\
\text { benefits }\end{array}$ & $\begin{array}{c}\text { Partial } \\
\text { materiality } \\
\text { calculated } \\
\text { for long-term } \\
\text { provisions } \\
\text { for employee } \\
\text { benefits }\end{array}$ & $\begin{array}{c}\text { Partial } \\
\text { materiality } \\
\text { calculated } \\
\text { for the gross } \\
\text { financial } \\
\text { result }\end{array}$ & $\begin{array}{c}\text { Change in } \\
\text { the average } \\
\text { balance } \\
\text { of long-term } \\
\text { provisions } \\
\text { for employ- } \\
\text { ee benefits } \\
\text { by 3\% }\end{array}$ & $\begin{array}{c}\text { Change in } \\
\text { the average } \\
\text { balance } \\
\text { of long-term } \\
\text { provisions } \\
\text { for employ- } \\
\text { ee benefits } \\
\text { by } 6 \%\end{array}$ & $\begin{array}{c}\text { Change in } \\
\text { the average } \\
\text { balance } \\
\text { of long-term } \\
\text { provisions } \\
\text { for employ- } \\
\text { ee benefits } \\
\text { by 9\% }\end{array}$ \\
\hline $\begin{array}{l}\text { 68 listed } \\
\text { companies }\end{array}$ & 1593954 & 94151 & 374590 & 47819 & 95637 & 143456 \\
\hline WIG 30 & 1482742 & 83379 & 308679 & 44482 & 88965 & 133447 \\
\hline mWIG40 & 12303 & 1828 & 16035 & 369 & 738 & 1107 \\
\hline sWIG80 & 30628 & 3443 & 22552 & 919 & 1838 & 2757 \\
\hline non-WIG & 68281 & 5500 & 27323 & 2048 & 4097 & 6145 \\
\hline
\end{tabular}

Source: own elaboration based on an analysis of the data contained in the financial statements of the listed companies, made available by those companies on their websites.

Table 8. Results of the study of the group of 115 companies

\begin{tabular}{|l|c|c|r|r|r|r|}
\hline Entities & $\begin{array}{c}\text { The average } \\
\text { balance } \\
\text { of long-term } \\
\text { provisions } \\
\text { for employee } \\
\text { benefits }\end{array}$ & $\begin{array}{c}\text { Partial } \\
\text { materiality } \\
\text { calculated } \\
\text { for long-term } \\
\text { provisions } \\
\text { for employee } \\
\text { benefits }\end{array}$ & $\begin{array}{c}\text { Partial } \\
\text { materiality } \\
\text { calculated } \\
\text { for the gross } \\
\text { financial } \\
\text { result }\end{array}$ & $\begin{array}{c}\text { Change in } \\
\text { the average } \\
\text { balance } \\
\text { of long-term } \\
\text { provisions } \\
\text { for employee } \\
\text { benefits } \\
\text { by } 3 \%\end{array}$ & $\begin{array}{c}\text { Change in } \\
\text { the average } \\
\text { balance } \\
\text { of long-term } \\
\text { provisions } \\
\text { for employee } \\
\text { benefits } \\
\text { by } 6 \%\end{array}$ & $\begin{array}{c}\text { Change in } \\
\text { the average } \\
\text { balance } \\
\text { of long-term } \\
\text { provisions } \\
\text { for employee } \\
\text { benefits } \\
\text { by 9\% }\end{array}$ \\
\hline $\begin{array}{l}115 \text { listed } \\
\text { companies }\end{array}$ & 2009771 & 141793 & 632917 & 60293 & 120586 & 180879 \\
\hline WIG 30 & 1771768 & 121120 & 480844 & 53153 & 106306 & 159459 \\
\hline mWIG40 & 70153 & 6286 & 39747 & 2105 & 4209 & 6314 \\
\hline sWIG80 & 92401 & 8094 & 78620 & 2772 & 5544 & 8316 \\
\hline non-WIG & 75449 & 6293 & 33705 & 2263 & 4527 & 6790 \\
\hline
\end{tabular}

Source: own elaboration based on an analysis of the data contained in the financial statements of the listed companies, made available by those companies on their websites.

The analysis showed that a small $(0.5 \%)$ change in the discounting parameters (both CAPM and WACC) results in a discount change by $1 \%$, which in long-term provisions may result in significant changes in the amount of provisions. These changes may be significant and, as a rule, affect the decisions of users of the financial statements.

Further on it was decided to expand the number of companies for the study to all the companies (from among the 148 companies) which presented provisions for employee benefits in a period of at least four out of the eight years covered by the 
study. These were 115 companies, which is $78 \%$ of all the companies in question. For this group of companies there were also calculated the rates of partial materiality of the long-term provisions for employee benefits and the gross financial result, also when divided into the companies listed on WIG30, mWIG40 and sWIG80, as well as the non-WIG companies.

The results of the study of the group of 115 companies are presented in Table 8, i.e. 115 companies out of 148 presenting provisions in at least four out of the eight years covered by the study.

The analysis showed that if the discount is changed by $2 \%$, eventually the estimate of the five-year provision is changed by over $9 \%$. When comparing the change by $9 \%$ of the amount of the long-term provisions for retirement benefits with the calculated partial materiality (relevance), it can be seen that such a change is relevant, and thus may significantly distort the entity's financial statements.

\section{Conclusions}

The consequence of applying prospective parameters of valuation is an increase in the significance of management estimates, and therefore the margin of the subjective shaping of reporting values, including the financial results achieved [Hońko, Kowalczuk 2014, p.86]. Numerous scientific studies have indicated that indeed, estimating the discount is an effective tool for manipulating the data disclosed in the financial statements [Budzińska 2011]. It is not true that the selection of an appropriate discount rate does not create problems to economic entities, and the possible differences resulting from the use of various solutions are small and irrelevant [Fish 2003]. The differences are large - depending on the assumptions adopted - and cannot significantly affect the amounts presented in the financial statements.

The article shows the ambiguity in determining the parameters of the CAPM and WACC model, and thus the ambiguity in determining the discount rate. In addition, according to Byrka-Kita [2004, p. 183], if the difficulties in determining the discount rate occur in the most developed markets in the world, it is obvious that discounting in countries with less developed capital markets is much more problematic. The discounting of provisions with the risk-rate may lead to a situation when entities with a poor financial standing will have a higher value of equity (and a lower value of liabilities) than the entities with a good financial standing [Bonham 2005, pp. 86-87].

All estimates - as can be concluded from their very nature - are characterized by high uncertainty and subjectivism. Provisions are a particular instrument of the balance sheet policy directly affecting the amount of the result presented in the financial statement and bringing a lot of possibilities to create it in the long and short-term [Poniatowska 2014, p. 269]. The general premise for treating provisions as an accounting policy tool that shapes the financial result is, precisely, their cost nature [Cebrowska 2003, p. 47]. 
The article presents the results of the sensitivity analyses of the discount rate in case of a change of selected parameters by $1 \%$ in order to check how a $1 \%$ change in a particular parameter will affect the change in the total discount rate. The sensitivity analysis showed that only one percentage change in the parameters used to determine the discount rate makes the discount rate also change by $1 \%$. It was calculated that in the case of discounting the amount of PLN 10,000 over a five-year period, a change in the discount rate by $1 \%$ results in a change in the amount of the provision by as much as $4.72 \%$, while a change in the discount rate by $2 \%$ results in a nearly $10 \%$ difference in the provision.

Empirical research was carried out on a group of 148 companies listed on the Warsaw Stock Exchange in 2014. The process of gathering empirical data (for further research) lasted from January 2013 to mid-2016, while all tests and calculations for the purposes of this article were carried out in 2018.

The analysis included the financial statements of every company for the years 2007-2008: a total of 1.184 financial statements made available by the surveyed companies on their websites were included in the analysis. After preliminary data analysis, subsequent tests were conducted for two selected groups of companies that recognized provisions for retirement benefits in every year of the eight years examined (group I: 68 companies in total) or recognized this type of provision at least in four out of the eight examined years (group II: 115 companies).

The research conducted on the group of 68 stock exchange quoted companies and 115 companies listed on the WSE showed that just a 1 or $2 \%$ change in the discount rate (which may result in a change of almost $9 \%$ in the provision) has a significant impact on the data included in the financial statement. Studies have shown that a reportedly slight change in the discount estimates ultimately has a large impact on the amount of the long-term provision for retirement benefits and may have a significant impact on the gross financial result: the hypothesis put forward by the authors is confirmed. It can also prove that the estimation of the discount rate significantly affects the level of costs related to the creation of provisions, which, unfortunately, can be an effective tool for manipulating financial results. The results of the research carried out by the authors coincide with the results of other researchers (e.g. [Amen 2007]) and once again confirm that provisions (especially the long-term provisions for employee benefits) are a category that can be successfully used for the discretionary shaping of the financial results of entities.

\section{Bibliography}

Amen M., 2007, Simulation-based comparison of existent IAS 19 Accounting Options, European Accounting Review, vol. 16, issue 2.

Amen M., 2008, Smoothing Effects of Different Ways to Cope with Actuarial Gains and Losses Under IAS 19, [in:] Fleischmann B., Borgwardt K.H., Klein R., Tuma A. (eds.), Operations Research Proceedings, https://link.springer.com/chapter/10.1007/978-3-642-00142-0_1 (28.05.2018). 
Bonham M., 2005, International GAAP 2005: Generally Accepted Accounting Practice Under International Financial Reporting Standards, LexisNexis, Warszawa.

Brigham E.F., Gapenski L.C., 2000, Zarzadzanie finansami, PWE, Warszawa.

Budzińska O., 2011, Wptyw szacowania stopy dyskontowej na wiarygodność wyceny wartości użytkowej środków trwałych, Prace i Materiały Wydziału Zarządzania Uniwersytetu Gdańskiego, no. 1/1.

Byrka-Kita K., 2004, Weryfikacja przydatności modelu wyceny aktywów kapitałowych (CAPM) w procesie szacowania kosztu kapitału własnego na polskim rynku kapitałowym, Zeszyty Naukowe Uniwersytetu Szczecińskiego, no. 389, Finanse, Rynki Finansowe, Ubezpieczenia, no. 2.

Cebrowska T., 2003, Wieloaspektowość pojęcia „rezerwy”, [in:] Cebrowska T., Dotkuś W. (eds.), Rachunkowość krajów w drodze do Unii Europejskiej. Rezerwy w rachunkowości, Wydawnictwo Akademii Ekonomicznej we Wrocławiu, Wrocław.

Demaria S., Dufour D., Louisy-Louis M., Luu P., 2012, An Exploratory Study of the Exposure Draft of IAS 19, conference proceedings, AFC 2012 - 33ème Congrès de l'Association Française de Comptabilité: Comptabilités et innovation, May 2012, Grenoble, France, https://hal.archives-ouvertes.fr/hal-00690943/document (28.05.2018).

Duliniec A., 2001, Struktura i koszt kapitału w przedsiębiorstwie, Wydawnictwo Naukowe PWN, Warszawa.

Duraj A.N., 2003, Funkcje rezerw w przedsiębiorstwie, Ekonomia, no. 11.

Gierusz J., 2005, Koszty i przychody w świetle nadrzędnych zasad rachunkowości. Pojęcia. Klasyfikacja. Zakres ujawnień, ODDK, Gdańsk.

Gos W., Hońko S., 2013, Pola rzeczoznawców majątkowych w wycenie bilansowej, [in:] Micherda B., Andrzejewski M. (eds.), 2013, Sprawozdawczość i rewizja finansowa. Problemy kwantyfikacji wartości, Wydawnictwo Uniwersytetu Ekonomicznego w Krakowie, Kraków.

Glaum M., Keller T., Street D.L., 2018, Discretionary accounting choices: The case of IAS 19 pension accounting, Accounting and Business Research, vol. 48, issue 2.

Grabowski R.J., Pratt S.P., 2008, Cost of Capital: Applications and Examples, John Wiley and Sons, New Jersey.

Hołda A., 2013, MSR/MSSF w polskiej praktyce gospodarczej, C.H. Beck, Warszawa.

Hołda A., 2015, Wartość godziwa wedlug MSSF oraz ustawy o rachunkowości, KIBR, Warszawa.

Hołda A., Staszel A., 2018, „Niskocenność” w rachunkowości na tle zmiany dolnej granicy środków trwatych, Rachunkowość, no. 3.

Hońko S., Kowalczuk J., 2014, Rachunek dyskontowy jako instrument prospektywnej wyceny w rachunkowości wedtug MSR/MSSF, Zeszyty Naukowe Uniwersytetu Szczecińskiego, no. 827, Finanse, Rynki Finansowe, Ubezpieczenia, no. 69.

Hsu A.W.H., Wu C.F., Lin J.C., 2013, Factors in managing actuarial assumptions for pension fair value: Implications for IAS 19, Review of Pacific Basin Financial Markets and Policies, vol. 16, issue 01

Kuzior A., 2014, Świadczenia pracownicze w rachunkowości jednostek gospodarczych, Zeszyty Naukowe Uniwersytetu Szczecińskiego, no. 827, Finanse, Rynki Finansowe, Ubezpieczenia, no. 69.

Ljubicic M., 2010, Earnings Management and Accounting Choice: Expected Return on Pension Plan Assets under IAS 19 - Empirical Evidence from Germany, Proceedings of the Northeast Business \& Economics Association.

Micherda B., 2009, Ustalanie wartości głównym posłaniem rachunkowości, Zeszyty Teoretyczne Rachunkowości, no. 53.

Ogier T., Rugman J., Spicer L., 2004, The Real Cost of Capital: A Business Field Guide to Better Financial Decisions, Pearson Education.

Peek E., 2004, The use of discretionary provision in earnings management. Evidence from the Netherlands, Journal of International Accounting Research, vol. 3, issue 2, pp. 27-43.

Poniatowska L., 2011, Metody wyceny rezerw, Zeszyty Naukowe Uniwersytetu Szczecińskiego, no. 669, Finanse, Rynki Finansowe, Ubezpieczenia, no. 41. 
Poniatowska L., 2012, Wycena rezerw na świadczenia pracownicze, [in:] Buk H. (ed.), Wycena zasobów gospodarczych dla potrzeb sprawozdawczości finansowej, Studia Ekonomiczne, Zeszyty Naukowe Wydziałowe Uniwersytetu Ekonomicznego w Katowicach, no. 82.

Poniatowska L., 2014, Polityka rachunkowości w zakresie rezerw na zobowiazania i jej znaczenie w kształtowaniu wyniku finansowego, Studia Ekonomiczne, Zeszyty Naukowe Uniwersytetu Ekonomicznego w Katowicach, no. 201.

Rakow K.C., 2010, The effect of management earning forecast characteristics on cost of equity capital, Advances in Accounting, Incorporating Advances in International Accounting, no. 26.

Ryba A., 2003, Stopa dyskontowa w rachunkowości, Prace Naukowe Akademii Ekonomicznej we Wrocławiu, no. 992.

Sharpe W., 1964, Capital Asset prices: A theory of market equilibrium, Journal of Finance, vol. 19, No. 3 (September).

Walińska E., Bek-Gaik B., 2010, Rezerwy jako instrument kształtujacy wizerunek przedsiębiorstwa w sprawozdaniu finansowym $w$ dobie kryzysu gospodarczego, Uniwersytet Ekonomiczny w Krakowie, Kraków.

Walińska E., Bek-Gaik B., 2012, Rezerwy jako istotna kategoria ksztaltująca wynik finansowy, Zeszyty Naukowe Uniwersytetu Szczecińskiego, no. 50.

Warelis A., 2011, Odzwierciedlenie rezerw na świadczenia pracownicze w sprawozdawczości finansowej, Zeszyty Teoretyczne Rachunkowości, no. 60.

\section{WPLYW ZMIAN SZACUNKÓW STOPY DYSKONTOWEJ NA KOSZTY TWORZENIA REZERW}

Streszczenie: Celem opracowania jest zweryfikowanie, w jaki sposób niewielka zmiana założeń aktuarialnych (dotyczących stopy dyskonta) wpływa na wielkość rezerwy, a finalnie kreuje poziom kosztów w jednostce. W ramach badań przeprowadzono analizę wrażliwości wielkości stopy dyskontowej oraz analizę wrażliwości dla rezerwy długoterminowej tworzonej przy zastosowaniu różnych poziomów dyskonta. Dokonano też analizy sprawozdań finansowych 148 spółek giełdowych z lat 2007-2014 (łącznie 1184 sprawozdań), sprawdzając, czy zmiany wielkości długoterminowych rezerw na świadczenia emerytalne (spowodowane zastosowaniem innego dyskonta) miały istotny wpływ na dane zawarte w tych sprawozdaniach. W badaniu wykorzystano dedukcyjno-indukcyjne metody badawcze: przegląd literatury oraz analizę treści sprawozdań finansowych. Otrzymane wyniki wskazują, że szacowanie stopy dyskontowej znacznie wpływa na poziom kosztów związanych z tworzeniem rezerw, przez co może być ono narzędziem do manipulowania wynikiem finansowym.

Słowa kluczowe: stopa dyskontowa, rezerwy na świadczenia emerytalne, wiarygodność sprawozdań finansowych, zasada true and fair view. 